\title{
Obesity: an asthma aggravating factor?
}

\author{
José Elabras Filho ${ }^{1 *}$, Sérgio Duarte Dortas Junior ${ }^{1,2}$, Elisabete Da Silva Blanc ${ }^{1}$, Cristiane Fernandes Moreira ${ }^{1}$, \\ Bruno Emanoel Carvalho Oliveira', Ana Carolina Miranda Carvalho Ferreira Fernandes De Sousa', \\ Alfeu Tavares França', Alfeu Tavares França ${ }^{3}$ \\ From 3rd WAO International Scientific Conference (WISC) 2014 \\ Rio de Janeiro, Brazil. 6-9 December 2014
}

\section{Background}

Several trials have demonstrated an association between obesity and asthma severity. Body Mass Index (BMI) is a metric used to estimate the amount of body fat. It's one of the best methods for population assessment of overweight and obesity. We have investigated the relationship between BMI and asthma severity in an adult asthmatic population from the Clinical Immunology outpatient service of an University Hospital.

\section{Methods}

142 adult patients, diagnosed by clinical spirometric findings as asthmatics, were divided in two groups based on their asthma severity: group 1 [ $(n=72)$ : Mild Intermittent and Mild Persistent Asthma] and group $2[(\mathrm{n}=$ 70): Moderate and Severe Persistent Asthma]. Patients BMI were calculated and compared between both groups.

\section{Results}

Patients mean age was 49.5 years-old, most of them were female and caucasian. $26.1 \%$ of them were former smokers. Mean weight was $66.17 \mathrm{~kg}$ in group 1 and $69.36 \mathrm{~kg}$ in group 2 . Mean height were $159.23 \mathrm{~cm}$ and $157.1 \mathrm{~cm}$ respectively. Mean BMI was significantly higher $(\mathrm{p}<0,05)$ in group $2(\mathrm{BMI}=28,06)$, comparing to group 1 (BMI=26,15).

\section{Conclusions}

In this study, BMI was associated with asthma severity.

\section{Authors' details}

${ }^{1}$ Hospital Universitário Clementino Fraga Filho Hucff-Ufrj, Brazil. ${ }^{2}$ Universidade Iguaçu, Brazil. ${ }^{3}$ Hospital São Zacharias, Brazil.

${ }^{1}$ Hospital Universitário Clementino Fraga Filho Hucff-Ufrj, Brazil Full list of author information is available at the end of the article
Published: 8 April 2015

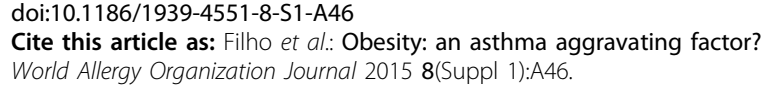

Submit your next manuscript to BioMed Central and take full advantage of:

- Convenient online submission

- Thorough peer review

- No space constraints or color figure charges

- Immediate publication on acceptance

- Inclusion in PubMed, CAS, Scopus and Google Scholar

- Research which is freely available for redistribution

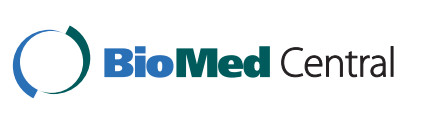

(c) 2015 Filho et al; licensee BioMed Central Ltd. This is an Open Access article distributed under the terms of the Creative Commons Attribution License (http://creativecommons.org/licenses/by/4.0), which permits unrestricted use, distribution, and reproduction in any medium, provided the original work is properly cited. The Creative Commons Public Domain Dedication waiver (http:// creativecommons.org/publicdomain/zero/1.0/) applies to the data made available in this article, unless otherwise stated. 